\title{
TEACHER ACTION RESEARCH IDEAS
}

\section{[MYSLIENKY O AKCNOM VYSKUME UCITELOV]}

\author{
Erich Petlak
}

doi: 10.18355/PG.2022.11.1.10

\begin{abstract}
The study analyzes action research in educational practice and its contribution to the quality of education. The author describes the difference between action research and the random application of methods, tools, or non-standard procedures in a teacher's work and analyzes teachers 'views on action research, as well as teachers' attitudes to research.
\end{abstract}

\section{Key words}

Action research, quality of education, attitudes of teachers to research

\section{Anotácia}

Štúdia analyzuje akčný výskum v edukačnej praxi a jeho prínos ku kvalite vzdelávania. Autor popisuje rozdiel medzi akčným výskumom a náhodným zaradením metód, prostriedkov, či neštandardných postupov v práci učitel'a a analyzuje názory učitel'ov na akčné skúmanie, ako aj postoje učitel'ov k výskumu.

Kl'účové slová

Akčný výskum, kvalita edukácie, postoje učitel'ov k výskumu

\section{Úvod}

K samozrejmým, ale najmä žiaducim požiadavkám spojením s edukáciou je akčný výskum učitel'a. Kurt Lewin, ktorý je považovaný za otca akčného výskumu zrejme nepredpokladal, že akčný výskum sa stane významnou a samozrejmou súčast'ou práce učitel'a (Adelman, 1993). Už dávnejšie sa ukázalo, že škola s jej klasickými metódami a formami práce nedokáže plnit' nové požiadavky, ktoré sú kladené na výsledky vzdelávania. V ostatných rokoch sa zdôrazňujú, napr. aj nové objavy neurovedy, ktorá výrazne ovplyvňuje edukáciu. Výsledkom aplikácie neuropedagogiky, neurodidaktiky je, napr. emocionalita vyučovania, možnosti rozvoja tvorivosti žiakov, hlboké učenie a vyučovanie a pod. Nové požiadavky je možné vnášat' do edukácie len vtedy ak sa bude venovat' pozornost' akčnému výskumu v radoch samotných učitel'ov.

\section{Podstata akěného výskumu}

Literatúra zaoberajúca sa touto oblast'ou je vel'mi rozsiahla. Aj z toho je zrejmé, že akčný výskum je pre reálnu edukačnú prácu mimoriadne dôležitý. Medzi akčným výskumom a výsledkami edukácie je priamy vzt’ah. Vyjadrujú to aj nasledovné definovania.

Akčný výskum v triede je zameraný na edukačnú činnost' a jej rozvoj. Motív 
spočíva vo vôli zlepšit' kvalitu vyučovania a učenia sa, ako aj podmienky, v ktorých učitelia a žiaci pracujú v školách. Pomáha učitel’om zvládat' výzvy a problémy inovácií $\mathrm{v}$ praxi reflexívnym spôsobom (Altrichter \& Posch, 2005).

Akčný výskum je metóda systematického skúmania, ktorú učitelia vykonávajú ako výskumníci svojej vlastnej praxe. Čerpajú zo zistení iných výskumníkov, aby mohli rozvíjat' činnosti a interpretovat' ich dôsledky (Spencer, Porath, S., Thiele, Jobe, 2020).

Akčný výskum je špecifický prístup $\mathrm{k}$ výskumu, ktorý sa priamo týka vyučovania a učenie $\mathrm{v}$ triede a poskytuje učitel'om prostriedky na zdokonalenie ich vyučovania a zlepšenie vzdelávanie študentov. Zd'aleka to nie je "niečo navyše", čo by učitelia museli vtesnat' do už aj tak náročného pracovného rozvrhu. Akčný výskum možno prepojit' s bežnými aktivitami v triede, poskytnút im podporu, ktorú potrebujú na zlepšenie učenia sa žiakov a ich vlastnej profesionálnej praxe. Flexibilita akčného výskumu zároveň poskytuje ostatným zainteresovaným stranám školy - vedeniu, žiakom, rodičom, svetu atd'., riešit' vel’a závažných problémov, ktoré sú súčast’ou komplexného života školy (Stringer, 2018).

Výstižne akčný výskum opisuje Koshy (2010). Podla neho je to konštruktívne skúmanie, počas ktorého si výskumník vytvára svoje poznatky o konkrétnych otázkach prostredníctvom plánovania, konania, hodnotenia, zdokonal'ovania a učenia sa zo skúseností. Ide o nepretržitý proces učenia sa, v ktorom sa výskumník učí a zároveň sa delí o novovytvorené poznatky s tými, ktorí z nich môžu mat’ prospech.

\section{Analýza vlastného vyučovania nemusí znamenat' akčný výskum}

Pre správne realizovanie akčného výskumu je potrebné, aby učitelia vedeli čo je jeho podstatou. Musia vediet' rozlišovat' čo je a čo nie je akčný výskum. Mnohí autori Mertler \& Charles, 2011; Janik 2004, Kompolt \& Timkova, 2010) opisujú podstatu akčného výskumu nasledovne - akčný výskum:

- je proces, ktorý zlepšuje vzdelávanie vo všeobecnosti tým, že prináša zmenu,

- je proces, na ktorom sa podiel'ajú pedagógovia, ktorí spolupracujú na zlepšení svojich vlastných postupov,

- nie je bežnou činnostou učitel'ov, ked' premýšlajú o vyučovaní; je systematickejší a založený na spolupráci,

- nie je len riešením problému; zahŕňa špecifikáciu problému, vývoj niečoho nového (vo väčšine prípadov) a kritickú reflexiu jeho účinnosti,

- sa nerobí "pre" alebo "inými lud'mi"; je to výskum, ktorý robia konkrétni pedagógovia na svojej vlastnej práci, so študentmi a kolegami,

- nie je len implementáciou vopred stanovených odpovedí na vzdelávacie otázky; skúma, objavuje a pracuje na tvorivých riešeniach vzdelávacích problémov,

- nie je definitívny; výsledky akčného výskumu nie sú ani správne, ani nesprávne, sú to skôr predbežné riešenia, ktoré vychádzajú z pozorovaní a iného zberu údajov a ktoré si vyžadujú monitorovanie a vyhodnocovanie s ciel'om identifikovat' silné stránky a obmedzenia,

- nie je „móda“, pretože dobré vyučovanie vždy zahŕňalo systematické 
skúmanie vyučovacieho procesu a jeho účinkov na učenie sa žiakov,

- rozvíja kritickú reflexiu vlastného vyučovania,

- je plánovaný, systematický prístup k pochopeniu procesu učenia,

- je proces, ktorý od nás vyžaduje, aby sme "testovali" naše predstavy o vzdelávaní,

- je zdôvodnením vlastných vyučovacích postupov,

- nemá striktný vedecký charakter, jeho úlohou nie je objavovat' zákonitosti a skúmat' teoretické aspekty edukácie, ale skúmat' podstatu istých pedagogických a didaktických javov, ktoré súvisia s edukačnou prácou učitel'a,

- výsledky skúmania sú hned' k dispozícii, a môžu sa implementovat' do edukačnej práce učitel'a.

Stručný výber pohl'adov na podstatu akčného výskumu spočíva $\mathrm{v}$ tom, že zdôrazňujú podstatu, ktorú si musia uvedomovat' učitelia, aby ich skúmanie prispelo k skvalitňovaniu vlastnej edukačnej činnosti.

Vel'a učitel'ov si myslí, že robia akčný výskum tým, že premýšl'ajú o vyučovaní a následne v ňom zmenia istý prvok. To nie je akčný výskum. Pre ten je typické nasledovné.

Akčný výskum:

- nie je len bežné premýšl'anie o vyučovaní,

- sa vyznačuje systematickou prácou učitel'a alebo kolektívu učitel'ov, s ciel'om skvalitnit' svoje edukačné činnosti a tým zvyšovat' kvalitu edukácie,

- nie je náhodná činnost', napr. len riešenie nejakej pedagogickej alebo didaktickej situácie, ktorá sa vyskytla vo vyučovaní,

- $\quad$ vychádza z doterajšej činnosti učitel'a, z jeho vlastnej sebareflexie,

- $\quad$ aj napriek istej jednoduchosti si vyžaduje isté metodologické vedomosti učitel'a,

- $\quad$ nie je a nemôže byt' len jednorazová akcia, pretože zistenia učitel'a ho vedú $\mathrm{k}$ d’alšiemu zdokonal'ovaniu svojej edukačnej činnosti.

V rámci nášho skúmania sme sa $v$ rozhovoroch $\mathrm{s}$ učitel'mi presvedčili, že systematický akčný výskum si zamieňajú s náhodným riešením niečoho, napr. vyskúšanie inej metódy vyučovania, pôsobenie na žiaka inou výchovnou metódou, zmena zasadacieho poriadku žiakov v triede, skúšanie viacerých motivačných metód a pod. Samozrejme, toto úsilie učitel'ov neodmietame, poukazujeme len na rozdiely akčného výskumu a iných, často náhodných pokusov a omylov v ich práci.

Každý krok akčného výskumu je mimoriadne významný pre celkovú úspešnost'. Z hl'adiska zamerania článku venujeme pozornost' najmä reflexii. Reflexia je koniec istého cyklu. V rámci nej učitel' prehodnocuje čo urobil a na základe toho prijíma rozhodnutia o d'alších pokračovaniach. Tie sa týkajú aplikácie zisteného do d’alšieho cyklu, ale aj uvedenie niečoho „nového“ do edukácie. Samozrejme, reflexia nie je len výsledkom v cykle, je súčast'ou všetkých fáz skúmania. Len vtedy je akčný výskum efektívny. 
Reflexia je v podstate priebežný monitoring v akčnom výskume.

\section{Názory učitel'ov na akčné skúmanie}

Akčný výskum sa v Európe, najmä v Anglicku začal rozvíjat' v 60. - 70. rokoch minulého storočia zásluhou Elliota, ktorý ho vnímal ako systematickú reflexiu profesijných situácií uskutočňovanú s ciel'om ich d'alšieho rozvinutia (Kosby, 2010, Kohutova, 2018). Sme svedkami temer dennej kritiky edukácie, ale najmä hl'adania efektívnejších metód a foriem edukačnej práce. Od akčného výskumu a jeho správneho využívania sa očakáva, že prispeje k zvyšovaniu efektívnosti edukácie.

Príkladom je aj uskutočnenie výskumu o akčnom výskume uverejnený na platforme School Education Gateway (Internet 2021). Do prieskumu bolo zapojených 144 respondentov z 25 krajín. Z výskumu vyplynulo, napr. že učitelia doceňujú akčný výskum ako možnost' zvyšovania kvality edukácie, považujú ho za účinný nástroj profesijného rozvoja učitel'a, prispieva k sebareflexii a ku kritickému mysleniu a pod. Súčasne však upozornili na vlastné nedostatočné vedomosti z oblasti výskumných metód, na nedostatok času na skúmanie a aj na to, že danej oblasti by mala byt' venovaná väčšia pozornost' aj zo strany vedenia škôl.

Z tohto výskumu uvedieme len pre zaujímavost' niektoré vybrané zistenia.

- $56 \%$ respondentov sa vyjadrilo v rozmedzí dobre alebo vel'mi dobre, že vedia čo je podstatou akčného výskumu, $18 \%$ neovláda podstatu akčného skúmania,

- $\quad 63 \%$ respondentov akčný výskum realizovala, ale len počas štúdia na učitel'ské povolanie, $33 \%$ v rámci učitel'ského pôsobenia, $37 \%$ takéto skúmanie nerealizovali,

- $16 \%$ respondentov uviedlo, že akčný výskum v ich krajine nie je rozšírení „stredne“, 16 \% uviedlo že vôbec nie je rozšírení, len 3 \% zastávajú názor, že je rozšrirený $\mathrm{v}$ ich krajine,

- $\quad 72 \%$ respondentov je toho názoru, že nie je $\mathrm{v}$ školách doceňovaný pre nedostatok vedomostí o výskume a $37 \%$ sa vyjadrilo o nedostatku podpory pre výskum.

$\mathrm{Z}$ d’alších názorov uvedieme len v krátkosti, napr. $72 \%$ respondentov vníma prínos výskumu pre prácu učitela, ako systematické zlepšovanie práce učitel'a oceňuje výskum $87 \%$ respondentov, $42 \%-47 \%$ sa vyjadrilo o tom, že by privítali väčšiu podporu, usmernenie, spoluprácu s inými vo výskume. V krátkosti opísané názory učitel’ov viacerých krajín sa stali pre nás podnetom pre zist'ovanie názorov našich učitel'ov na akčný výskum. $\mathrm{V}$ rámci atestačného vzdelávania učitel'ov sme uskutočnili rozhovory (92 učitel'ov) na tému akčného výskumu, aby sme zistili ich názor, postoje, prípadne problémy v tejto oblasti. Naše skúmanie, resp. zist'ovanie nevyhodnocujeme štatistickými metódami, ide nám predovšetkým o isté postojové stanoviská, ktoré sú reflexiou názorov učitel’ov. 


\section{Postoje učitel’ov k výskumu}

$\mathrm{Z}$ rozhovorov s učitel'mi vyplynulo, že akčný výskum nepatrí k prioritám ich práce. Za prioritu považujú dobré výsledky edukačnej činnosti, pretože tá je hodnotená vedením školy a rodičmi. To je realita, ktorá odráža, že učitelia si neuvedomujú, že využívanie akčného výskumu môže významne prospiet' k zvýšeniu kvality ich práce. Je to ani nie prejav nevedomostí alebo nedocenenia inovatívnych možností v edukácii prostredníctvom akčného skúmania, ale predovšetkým sústredenie sa na finálny výsledok - vedomosti žiakov. V rozhovoroch sme zaznamenali aj poznámky týkajúce sa istej nekompetentnosti. Lepšie je vyjadrenie „sebanekompetentnosti“ - učitel'om akoby chýbala odvaha realizovat' skúmanie. Neraz sa vyjadrovali, že im postačuje analýza vlastnej práce, ktorá im naznačuje čo je potrebné zlepšit'. $\mathrm{V}$ tejto súvislosti by sme mohli rozpisovat' vzt'ahy medzi modernizáciou edukačných procesov a ich efektívnostou. $Z$ uvedeného vyplýva potreba viac pozornosti na všetkých úrovniach venovat' „výskumnému vedomiu“ učitel’ov. Iba v krátkosti poznamenáme, že výskum musí byt' v súčasnosti integrálnou súčast'ou pedagogickej práce učitela.

Učitelia akčný výskum teoreticky doceňujú avšak reálnej edukačnej praxi nie je tak využívaný ako by sa žiadalo. V čom spočívajú pričiny uvedeného stavu. Ak vychádzame z pohl'adu učitel'ov konštatujeme, že podiel na tomto majú aj riadiace orgány školstva. Učitelia sú toho názoru že zo strany riadenia školstva, teda $\mathrm{v}$ makroriadení nie je tomuto venovaná náležitá pozornost', čo sa následne prenáša a prejavuje aj mikroriadení - riaditel' a vedenie školy. Viacej učitel’ov sa vyjadrilo. že vedenie školy neposkytuje učitel’om pomoc. výskum nepovažujú za prioritu a pod. Uvedené zistenia majú vel'kú výpovednú hodnotu a naznačujú, že príčiny nespočívajú len $\mathrm{v}$ učitel'och, ale aj v riadení.

Ukázalo sa, že aj v príprave budúcich učitel'ov tejto stránke nie je venovaná taká pozornost' ako by bolo žiaduce. O tomto sa respondenti najčastejšie vyjadrovali v rozhovoroch a uvádzali, že s výskumom sa odbornejšie zaoberali len pri spracúvaní záverečnej práce štúdia, a tak si nevytvorili vzt’ah ku skúmaniu.

Skutočnost', že učitelia nevedia posúdit' prístupy ku skúmaniu u svojich kolegov svedčí o tom, že výskum nepatrí do „portfólia“ diskusií o možnostiach skvalitňovania edukácie. Z vyjadrení učitel'ov: „Skúmaním sa zaoberám najmä vtedy ak sa mi v práci nedarí.", „S kolegami sa často radíme o metódach vyučovania, ale nerobíme niečo také čo by som nazval skúmanim."

Pozornost' si zasluhuje, že učitelia akčný výskum spájajú len s priamym vyučovaním. Menej si uvedomujú alebo doceňujú, že ich vlastné skúmanie im odhal'uje slabé miesta $\mathrm{v}$ ich edukačnej činnosti - prispieva $\mathrm{k}$ zdokonaleniu sebareflexie, ale aj k spolupráci s ostatnými kolegami. Akčný výskum nie je len bezprostredné skúmanie vyučovania, ale aj skúmanie a následné zlepšovanie mnohých súvisiacich aspektov. Na otázku v čom vidia zmysel výskumu, sme najčastejšie zaznamenali odpovede: „Zlepšit' vyučovanie.“, „Podstata akčného výskumu spočíva v tom, aby som viacej a lepšie naučil.“ Povedané inak - učitelia chápu skúmanie predovšetkým ako utilitarizmus. 
Viacerí učitelia si neuvedomujú, že ak akčným výskumom dospeje $\mathrm{k}$ lepším progresívnejším a afektívnym metódam vyučovania, potom bude učit' efektívnejšie $\mathrm{v}$ zmysle osvedčeného - v krátkom čase, $\mathrm{s}$ menšou námahou učitel'a a žiaka, dosiahnutie lepšieho výsledku. $\mathrm{V}$ tom spočíva podstata a význam skúmania. Nízke percentá o osobnom záujme a iných činitel’och, ktoré pôsobia na skúmanie, sú uspokojujúce len tým, že je to len nízky počet.

Z viacerých zistení uvedieme, že učitelia si v zásade uvedomujú viaceré prednosti akčného výskumu. Najmä výsledky týkajúce sa pomoci učitel'om vo výskume zo strany vedenia škôl by mali byt' pre nás istou výzvou pre zlepšenie jestvujúceho stavu. To isté však platí, napr. aj pre d’alšie možnosti a činnosti, napr. organizovanie takých školení a seminárov pre učitel'ov, ktoré budú pre nich zrozumitel'né a motivačné, písanie štúdií podporujúcich rozvíjanie akčného výskumu v školách a pod. Uvedené je výzva pre mnohých autorov, ktorí chcú prispiet' $\mathrm{k}$ zlepšeniu jestvujúceho stavu $\mathrm{v}$ akčnom výskume $\mathrm{v}$ školách.

Všetci učitelia majú isté skúsenosti s výskumom zo svojho štúdia, ale problém je $\mathrm{v}$ tom, že $\mathrm{v}$ tom $\mathrm{v}$ tomto skúmaní nepokračujú $\mathrm{v}$ rámci svojej pedagogickej práce, nerozvíjajú potenciálne možnosti pre skvalitňovanie a zefektívňovanie výučby. Realita je taká, že ani atestačné vzdelávanie, ktoré učitelia absolvovali a ešte aj absolvujú neprináša zásadnejšie výsledky v tejto oblasti.

Na druhej strane však treba uviest', že sú aj učitelia, ktorí akčný výskum vnímajú ako isté prepojenie medzi ich činnost'ou a d’alším zdokonal'ovaním svojej práce. Čo je však cennejšie, vnímajú ho pomoc svojim žiakom - to je, nazvime to vyšší level, ked' učitel' vidí výsledok skúmania nielen vo vzt’ahu $\mathrm{k}$ sebe samému, ale aj vo vzt'ahu $\mathrm{k}$ jeho žiakom.

Pre objektívnost' však považujeme za potrebné uviest' aj skutočnost', že nielen samotní učitelia sú „vinní“ za to, že výskum nie je v našich školách úplnou samozrejmost'ou v činnosti každého učitel'a - to, že učitelia sú neraz pret’ažení inými ako pedagogickými činnost’ami je každému známe, a teda učitelia aj $\mathrm{v}$ tejto oblasti potrebujú motivačné povzbudzovanie, odbremeňovanie od byrokracie a sústredenie sa viacej im pomáhat' $\mathrm{v}$ sebareflexii a v akčnom výskume.

\section{Bibliographic references}

Adelman, C. (1993). Kurt Lewin and the Origins of Action Research. In Educational Action Research, 1(1)

Alrichter, H. \& Posch, P. (2007). Lehrerinen und Lehrer erforschen ihren Unterricht. Unterrichtsentwicklung und Unterrichtsevaluation durch Aktionforschung. Bad Heilbrunn, Verlag J. Klinghardt.

Janik, T. (2004). Akcni vyzkum jako cesta ke zkvalitneni pedagogicke praxe. In Manak, J. \& Svec, V. Cesty pedagogickeho vyzkumu. Brno, Paido.

Kohutova, K. (2018) Vnimana profesijna zdatnost ucitela - overenie psychometrickych vlastnosti dotaznika OSTES. In Slavonic Pedagogical Studies Journal. 7(2), pp. 281-292. 
Kompolt, P. \& Timkova, B. (2010). Pedagogicka diagnostika a akcny vyskum. Bratislava, Univerzita Komenskeho.

Koshy, V. (2010). Action research for improving educational practice: A step-by-step guide. London, Sage.

Meltler, C. A. \& Charles, C. M. (2011). Introductional to ducational research. 7th ed. Boston, Pearson/Allyn \& Bacon.

School Education Gateway (2021). Rezultati raziskave o akcijskem raziskovanju v razredu.

www.schooleducationgateway.eu/sl/pub/viewpoints/surveys/surveyaction-research-schools.htm

Spencer, J. C., Porath, S., Thiele, J. \& Jobe, M. (2020). Action Research. Manhattan, Kansas State University Libraries.

https://newprairiepress.org/ebooks/34.

Stringer, E. (2008). Akcijsko raziskovanje v izobrazevanju. Kranj, Sola za ravnatelje, zanjo dr. Andrej Koren.

prof. PhDr. Erich Petlák, CSc.

Faculty of education

Catholic University in Ruzomberok

Hrabovská cesta 1, 03401 Ružomberok

Slovakia

erich.petlak@ku.sk 